\title{
$\mathrm{W}-\mathrm{M}(\mathrm{M}=\mathrm{Cu}, \mathrm{Sn}, \mathrm{Ni})$ 계 고밀도 복합재료 제조에 관한 기초연구(I) \\ 장탁순 $\cdot$ 홍준희 $\cdot$ 이태행 $a$ 구자명 $a$ 송창빈 ${ }^{a *}$ * \\ 충남대학교 기계공학부, ${ }^{a}$ 공주대학교 신소재공학부
}

\section{A Basic Study on the Fabrication of W-M(M=Cu, Sn, Ni) System High Density Composite (I)}

\author{
Tak-soon Jang, Jun-Hee Hong, Tae-haeng Lee ${ }^{a}$, Jar-Myung Koo ${ }^{a}$ and Chang-Bin Song ${ }^{a}$ * \\ Div. of Mechanical Engineering, Chungnam National University, Daejon 305-764, Korea \\ ${ }^{a}$ Div. of Advanced Materials Engineering, Kongju National University, Kongju 314-701, Korea
}

(Received May 29, 2009; Revised June 25, 2009; Accepted July 7, 2009)

\begin{abstract}
For the purpose of obtaining basic information on the development of lead-free materials, a high density composites (a) W-Cu, (b) W-Sn (c)W-Cu-Sn and (d) W-Cu-Ni were fabricated by the P/M method. The particle size of used metal powders were under 325 mesh, inner size of compaction mould was $\varnothing 8 \mathrm{~mm}$, and compaction pressure was $400 \mathrm{MPa}$. A High density composite samples were sintered at a temperature between $140^{\circ} \mathrm{C}$ and $1050^{\circ} \mathrm{C}$ for 1 hour under Ar atmosphere. The microstructure, phase transformation and physical properties of the sintered samples were investigated. As the results, the highest relative density of $95.86 \%\left(10.87 \mathrm{~g} / \mathrm{cm}^{3}\right)$ was obtained particularly in the sintered W-Cu-Sn ternary system sample sintered at 450 for $1 \mathrm{hr}$. And, Rockwell hardness (HRB) of 70.0 was obtained in this system.
\end{abstract}

Keywords : High density composite, P/M method, Tungsten, Copper, Tin, Nickel

\section{1. 서 론}

최근 산업의 발전과 더불어 유독성 중금속(납, 수 은, 카드뮴 등) 사용의 급증과 함께 전통적으로 사용 되고 있는 낚시나 그물 추, 레저 스포츠 및 수렵용 엽총탄환 소재인 납(lead)은 지표면의 토양이나 지하 수 오염뿐만 아니라, 자연 생태계의 연쇄적인 파괴의 주범으로 알려져 있다. 그에 따른 대책으로 미국, 캐 나다에서는 1990년 초부터 모든 조류 및 포유동물 수렵 시 납 탄알 사용을 전면적으로 금지하고 있으 며, 국내에서도 2003년부터 레저 스포츠 클레이 사 격장에서 납 탄알의 제한적 사용을 시작으로 2005년 부터는 모든 클레이 사격장 및 수렵장에서 전면적으 로 금지하는 등, 유독성 중금속 사용을 억제하는 규 제를 법제화하여 운영하고 있다. 특히 이러한 유독성 의 소화기용 납 탄알을 대체할 수 있는 소재로는, 표
1에 나타낸 순금속들이 있으나, 이들 금속은 대부분 희유금속으로 분류되어 부존자원이 부족할 뿐만 아 니라, 매우 고가이다.

현재 이러한 소화기 탄환용 고밀도 소재개발에 관 한 연구 및 실용 특허기술의 보고는 미국이나 유럽 등 외국에서 수행된 것이 대부분이며[1-9], 그들 중에서 그림 1 및 그림 2는 미국의 Brian M. 등[5]이 무연 탄환(Lead-free bullet)의 소재개발에 관한 것으로서, $\mathrm{W}, \mathrm{FeC}, \mathrm{WFe}$ 등의 고밀도 구성 물질과 그들의 결합 물질(binder)로 $\mathrm{Sn}, \mathrm{Bi}, \mathrm{Zn}, \mathrm{Al}$ 및 $\mathrm{Cu}$ 등을 사용하여 주로 소결체의 밀도 및 기계적 특성을 보고하는 한편, 새로운 친환경 탄환용 소재개발을 위해서는 다음과 같 은 6 가지 특성이 중요함을 강조하고 있다.

[1] 납탄과 유사한 되튐성(recoil)을 가질 것

[2] 우수한 탄도(trajectory) 특성을 가질 것

[3] 과도한 관통(penetration)과 도탄(ricochet)이

*Corresponding Author : [Tel : +82-41-521-9374; E-mail : cbsong@kongju.ac.kr] 
Table 1. All sort of pure metals and their densities

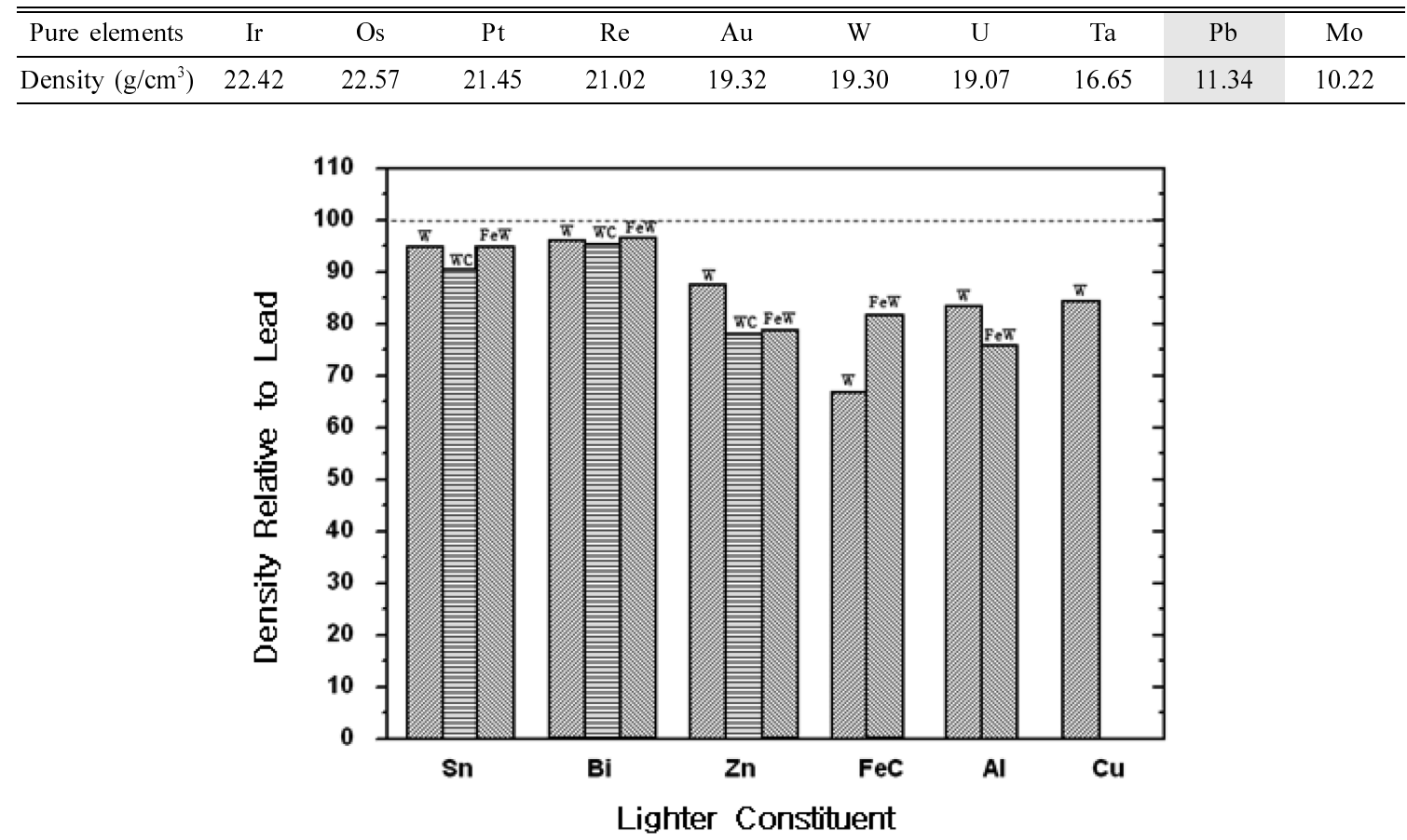

Fig. 1. A bar graph of densities of powder composites.

적을 것

[4] 총열에 손상을 주지 않고, 탄두 자체의 변형이 적을 것

[5] 부식(erosion)이 적을 것

[6] 경제성(reasonable cost)이 양호 할 것

한편 국내의 경우, 이러한 새로운 친환경 탄환용 소재개발을 위해 본 연구팀에 의해 몇 년 전부터 수행해 온 텅스텐계 고밀도 복합재료에 관한 몇몇 의 기초연구결과[19-26]가 전부이다. 그 밖에 W$\mathrm{Fe}-\mathrm{Ni}(\mathrm{Co})$ 계 중합금(heavy alloy)[10-13] 및 W-Cu 계 복합재료[14-18] 등에 관한 연구보고가 다수 있 지만, 전자의 $\mathrm{W}-\mathrm{Fe}-\mathrm{Ni}(\mathrm{Co})$ 계 중합금은 국방용 대전 차 장갑판 파괴를 위한 관통자(penetrator)용, 후자 의 $\mathrm{W}-\mathrm{Cu}$ 계 복합재료는 주로 전기 - 전자부품 소재 용에 국한된 것으로 상기한 소화기 탄환용 고밀도 소재로는 적합하지 않다.

따라서 본고는 소화기용 납 탄환을 대체할 수 있는 새로운 친환경 탄환소재를 개발하기 위한 일환으로, 비교적 가격적으로 저렴하고 손쉽게 입수 가능한 텅

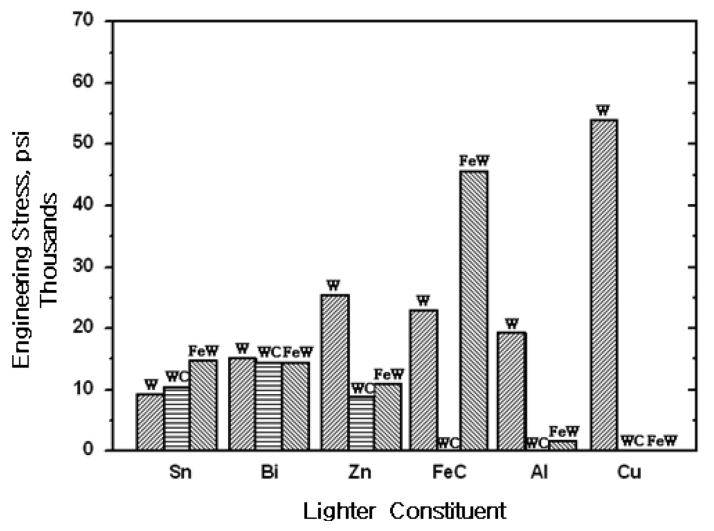

Fig. 2. A bar graph of maximum engineering stress attained with the powder composites.

스텐 $(\mathrm{W})$ 금속분말을 이용하여 납 $(\mathrm{Pb})$ 의 이론비중인 $11.34 \mathrm{~g} / \mathrm{cm}^{3}$ 을 목표비중으로 하여 $\mathrm{W}-\mathrm{M}(\mathrm{M}=\mathrm{Cu}, \mathrm{Sn}$, $\mathrm{Ni}$ )ㅖ 고밀도 복합재료를 $\mathrm{P} / \mathrm{M}$ 법으로 제조하였으며, 그 에 따른 복합재료 소결체의 압축성형, 소결특성, 미세 조직 관찰 및 물리적 · 기계적 특성 등을 보고한다. 


\section{2. 실험방법}

본 연구에서 사용한 고밀도 복합재료 소결체의 원 료분말은 텅스텐( $2 \mathrm{~N},-1340 \mathrm{mesh})$, 구리(3N, -325 mesh), 니켈(3N, -325 mesh) 및 주석(3N, -325 mesh) 으로 상용 시약용 분말이며, 고밀도 복합재료 분말시 료의 총량은 납탄 $(\mathrm{Pb})$ 의 이론비중 $\left(11.34 \mathrm{~g} / \mathrm{cm}^{3}\right)$ 에 맞 도록 $3.5 \mathrm{~g}$ 되도록 천평하여 agate막자사발로 혼합하 여 사용하였다. 표 2는 본 연구에서 $\mathrm{W}-\mathrm{M}(\mathrm{M}=\mathrm{Cu}$, $\mathrm{Sn}, \mathrm{Ni}$ )계 복합재료 설계 시 사용한 목표비중 및 화 학조성이며, 혼합된 분말은 $\varnothing 8 \mathrm{~mm}$ 금형다이를 사용 하여 $400 \mathrm{MPa}$ 로 일방향(상하) 압축 성형하였으며, 성형된 합금분말 성형체는 튜브 전기로를 이용하여 $\mathrm{Ar}$ 분위기에서 소정온도 $\left(140 \sim 1050^{\circ} \mathrm{C}\right)$ 에서 소정시간 소결하였다. 소결된 시료는 아르키메디안 비중측정법 으로 비중을 측정하였으며, 그 밖에 광학현미경에 의 한 미세조직 관찰 및 Rockwell 경도를 측정하였다.

\section{3. 실험결과 및 고찰}

\section{1. 복합재료 원료분말의 압축성형}

그림 3 및 그림 4 는 표 1 에 나타낸 $\mathrm{W}-\mathrm{M}(\mathrm{M}=\mathrm{Cu}$, $\mathrm{Sn}, \mathrm{Ni}$ )계 고밀도 복합재료 소결체의 비중이 납과 동 일한 비중이 되도록 (a)W-Cu 2원계, (b)W-Sn 2원계, (c)W-Cu-Sn 3원계 및 (d)W-Cu-Ni 3원계 원료분말 을 각각 혼합하여 일방향으로 압축성형한 각 성형체 의 외형과 성형밀도를 나타낸 것이다. 이들 성형체의 높이 $(\mathrm{H})$ 와 직경 $(\mathrm{D})$ 의 비율 $(\mathrm{H} / \mathrm{D}$ 비 $)$ 은 버니어 켈리퍼 스로 측정한 결과 약 0.77 이었다. 각 복합재료 성형 체의 이론밀도에 대한 상대 성형밀도(compaction density)는 $91 \%$ 이상으로 비교적 높게 나타났지만, 그 들 중에서도 (b)W-Sn 2원계가 $95.43 \%(10.82 \mathrm{~g} /$

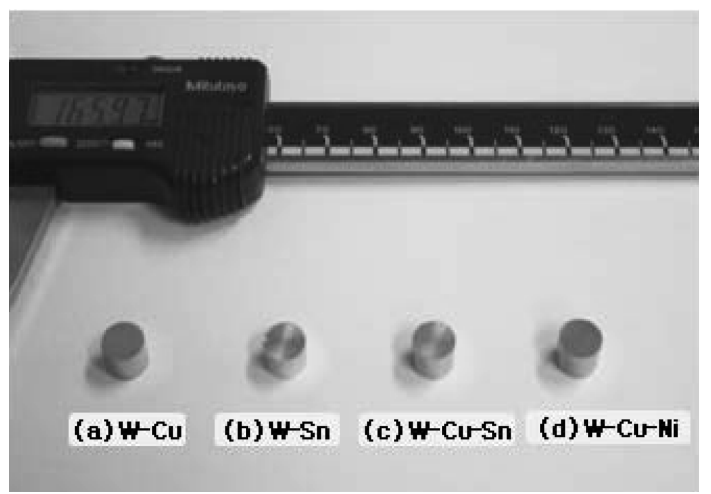

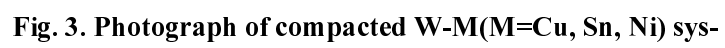
tem composite samples.

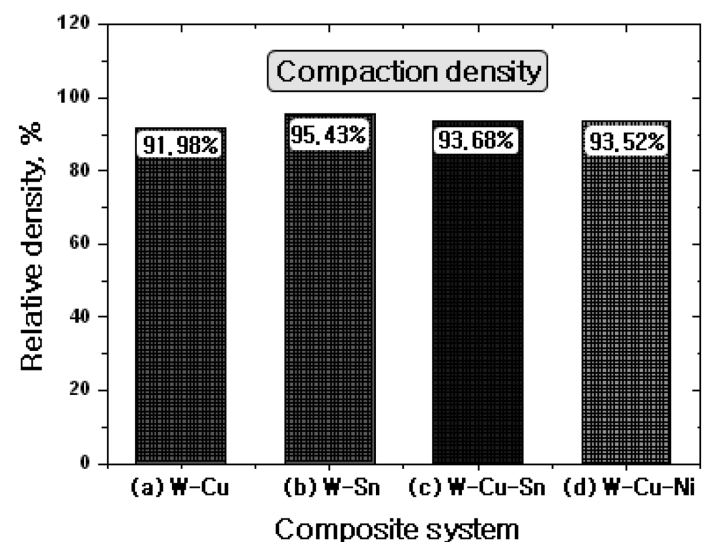

Fig. 4. Comparisons of relative density of compacted W$M(M=C u, S n, N i)$ system composite samples with 400 MPa.

$\mathrm{cm}^{3}$ 로 가장 높게 나타났다. 일반적으로 금속분말의 성형밀도는 $\mathrm{H} / \mathrm{D}$ 비, 입자의 형상, 크기 및 입도분포 등의 분말의 외적 요소나, 금속분말 자체 내부 기공 의 존재여부 및 경도 등의 내적 요소에 의존할 수

Table 2. Targets and chemical compositions of $\mathrm{W}-\mathrm{M}(\mathrm{M}=\mathrm{Cu}, \mathrm{Sn}$, Ni) system composite

\begin{tabular}{|c|c|c|c|c|c|c|}
\hline \multirow{2}{*}{$\begin{array}{c}\text { Composite } \\
\text { materials }\end{array}$} & \multirow{2}{*}{$\begin{array}{l}\text { Target density } \\
\left(\mathrm{g} / \mathrm{cm}^{3}\right)\end{array}$} & \multicolumn{4}{|c|}{ Chemical composition (wt\%) } & \multirow{2}{*}{ Sintering conditions } \\
\hline & & $\mathrm{W}$ & $\mathrm{Cu}$ & $\mathrm{Ni}$ & Sn & \\
\hline (a)W-Cu & 11.34 & 39.65 & 60.35 & - & - & $\left(850 \sim 1050^{\circ} \mathrm{C}\right) * 1 \mathrm{hr}$ \\
\hline (b)W-Sn & 11.34 & 57.49 & - & - & 42.51 & $\left(140 \sim 220^{\circ} \mathrm{C}\right) * 1 \mathrm{hr}$ \\
\hline (c) W-Cu-Sn & 11.34 & 41.87 & 52.85 & - & $\begin{array}{c}5.28 \\
(\mathrm{Cu} \text { 의 } 10 \%)\end{array}$ & $\left(400 \sim 850^{\circ} \mathrm{C}\right)^{*} 1 \mathrm{hr}$ \\
\hline (d)W-Cu-Ni & 11.34 & 39.67 & 54.85 & $\begin{array}{c}5.48 \\
(\mathrm{Cu} \text { 의 } 10 \%)\end{array}$ & - & $\left(850 \sim 1050^{\circ} \mathrm{C}\right)^{*} 1 \mathrm{hr}$ \\
\hline
\end{tabular}


있다. 본 연구에서는 성형밀도에 미치는 상기한 내· 외적 요소 등을 상세하게 조사하지 않았지만, 특히 (b)W-Sn 2원계의 성형밀도가 가장 높게 나타난 것은 $\mathrm{Sn}$ 분말의 경도가 $\mathrm{Cu}$ 및 $\mathrm{Ni}$ 보다 낮은 것에 기인한 것으로 추측되었다.

\section{2. 소결체의 소결거동 및 미세조직}

그림 5 는 표 2와 그림 3 에 나타낸 $\mathrm{W}-\mathrm{M}(\mathrm{M}=\mathrm{Cu}$, $\mathrm{Sn}, \mathrm{Ni}$ )ㅖ 4 가지 고밀도 복합재료를 동일한 성형조건 으로 압축성형하여 소결온도를 1시간으로 고정하고, 텅스텐 $(\mathrm{W})$ 을 제외한 각 금속분말의 융점부근까지 각 복합재료의 소결온도를 변화시켜 소결하여 얻어진 소 결체 시료 중에서 최고의 비중을 나타낸 각 소결체의 단면을 광학현미경 $(\mathrm{OM})$ 으로 관찰한 결과이다. 각 소 결체 시료의 단면 사진에 회색으로 관찰되는 미세조 직은 금속 텅스텐 $(\mathrm{W})$ 입자이며, 검게 보이는 것은 소 결 시 생성된 기공이다. 그림 5-(a) W-Cu 2원계는 $850,900,950,1000$ 및 $1050^{\circ} \mathrm{C}$ 에서 각각 1 시간 소 결한 시료 중, $1000^{\circ} \mathrm{C}$ 에서 소결한 미세조직으로 원래 $\mathrm{W}$ 와 $\mathrm{Cu}$ 는 고용도(solubility)가 거의 없기 때문에 각 원자의 상호확산에 의한 것보다 단지 $\mathrm{Cu}$ 입자의 고상
소결에 의한 치밀화가 주로 진행된 것으로 추측되었 다. 3 5 $\mu \mathrm{m}$ 정도 크기의 미세기공이 주로 밀집된 $\mathrm{W}$ 입자의 주위 혹은 $\mathrm{W}$ 과 $\mathrm{Cu}$ 입자의 경계에서 관찰되 었으며, 이러한 W-Cu 2원계는 4가지 고밀도 복합재 료 중 큰 기공이 관찰되었다. 그림 5-(b)의 W-Sn 2 원계는 소결온도를 $140,160,180,200^{\circ} \mathrm{C}$ 및 $220^{\circ} \mathrm{C}$ 에서 각각 1 시간동안 소결한 시료 중에서 $\mathrm{Sn}$ 의 융점 에 근접한 $200^{\circ} \mathrm{C}$ 에서 소결한 것이 비교적 기공이 적 고, 소결상태가 양호하였으며, 30 40 $\mu \mathrm{m}$ 정도의 $\mathrm{Sn}$ 입 자가 관찰되었다. 그림 5-(c)의 W-Cu-Sn 3원계는 $400,450,500,550,600,650,700,800$ 및 $850^{\circ} \mathrm{C}$ 에서 각각 1 시간동안 소결한 시료 중, $450^{\circ} \mathrm{C}$ 에서 소 결한 것으로 미세조직은 (a)W-Cu 2원계 소결체와 유 사하게 밀집된 $\mathrm{W}$ 입자의 주위에서 주로 관찰되었으며, $\mathrm{W}-\mathrm{Cu}$ 2원계보다 기공의 수도 적고, 크기도 적게(2 3 $\mu \mathrm{m}$ 정도) 관찰되었다. 또한 그림 5-(d)는 $\mathrm{W}-\mathrm{Cu}-\mathrm{Ni} 3$ 원계는 $850,900,950,1000$ 및 $1050^{\circ} \mathrm{C}$ 에서 각각 1 시간동안 소결한 결과, 대부분의 시료에서 (a)W-Cu 2 원계보다 기공 수가 적고 그 크기도 작은 것으로 관 찰되었으며, $\mathrm{W}$ 입자(사진의 회색 입자)와 고상확산에 의해 생성된 $\mathrm{Cu}-\mathrm{Ni}$ 합금상으로 추측된 입자가 비교
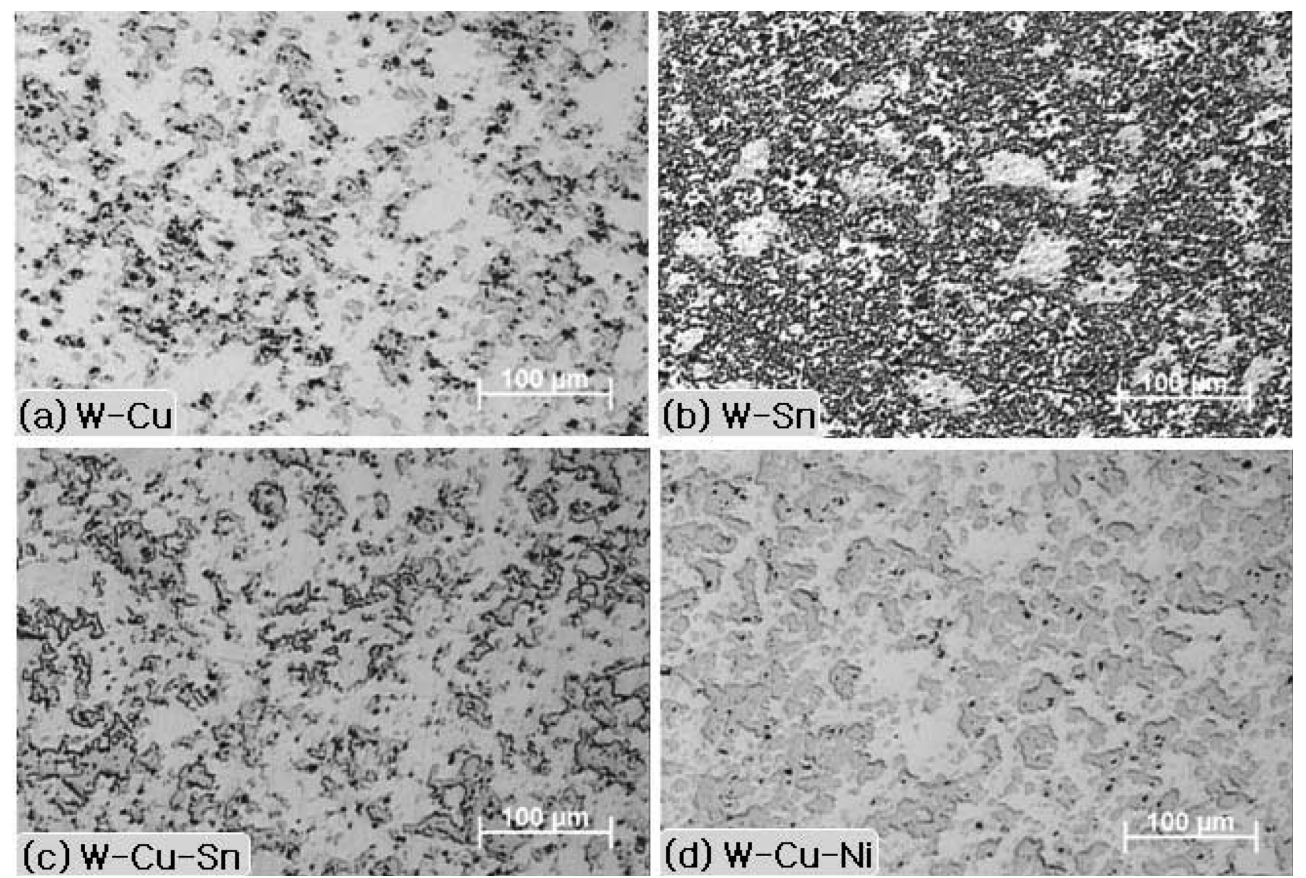

Fig. 5. OM microstructures of sintered $\mathrm{W}-\mathrm{M}(\mathrm{M}=\mathrm{Cu}, \mathrm{Sn}, \mathrm{Ni})$ system composite samples; (a)W-Cu system at $900^{\circ} \mathrm{C}$ for $1 \mathrm{hr}$, (b)W-Sn system at $180^{\circ} \mathrm{C}$ for $1 \mathrm{hr}$, (c)W-Cu-Sn system at $450^{\circ} \mathrm{C}$ for $1 \mathrm{hr}$, and (d)W-Cu-Ni system at $1000^{\circ} \mathrm{C}$ for $1 \mathrm{hr}$. 


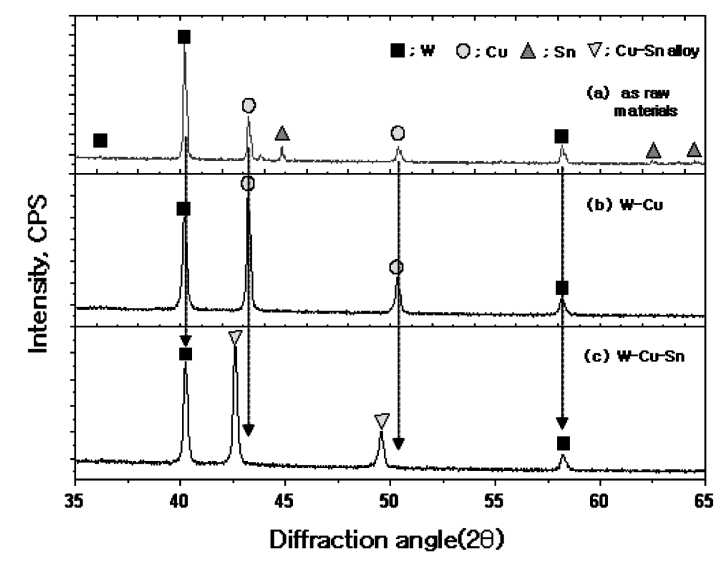

Fig. 6. Comparison of XRD patterns of each samples prepared by sintering conditions; (a) as raw powders of $W$ Cu-Sn system, (b) W-Cu system at $1000^{\circ} \mathrm{C}$ for $1 \mathrm{hr}$, (c) W$\mathrm{Cu}-\mathrm{Sn}$ system at $850^{\circ} \mathrm{C}$ for $1 \mathrm{~h}$.

적 균질하게 고상소결이 진행되어 치밀화가 이루어 진 것으로 관찰되었다. 특히 상기한 $\mathrm{W}$ 입자(사진의 회색 입자)의 크기가 (a)W-Cu 2원계, (b)W-Sn 2 원계 및 (c)W-Cu-Sn 3원계에 비교하여 약간 크게 관찰되었으며, 그러한 이유는 $\mathrm{W}$ 과 $\mathrm{Ni}$ 입자가 상호 확산하여 W-Ni합금이 생성되었기 때문으로 추측되 었다.

그림 6 은 W-Cu 2원계 및 W-Cu-Sn 3원계의 소 결 전 혼합분말 시료와 소결체를 $\mathrm{XRD}$ 로 상변화를 비교 분석한 결과이다. 그림 6-(a)는 소결 전의 W$\mathrm{Cu}-\mathrm{Sn}$ 3원계 원료분말을 측정한 것으로 각 원소에 대한 peak가 선명하게 관찰되었으며, 그림 4-(b)는 $\mathrm{W}-\mathrm{Cu}$ 2원계 원료분말을 $1000^{\circ} \mathrm{C}$ 에서 1 시간 동안 소 결한 것으로 새로운 합금상이 관찰되지 않고 텅스텐 과 구리에 해당되는 2 개의 peak만 관찰되었다. 이러 한 결과는 원래 $\mathrm{W}$ 와 $\mathrm{Cu}$ 는 고용도(solubility)가 거의 없어 각 원자의 상호확산이 일어나지 않았기 때문으 로 추측되었다. 그리고 그림 6-(c)의 W-Cu-Sn 3원계 는 $\mathrm{W}-\mathrm{Cu}$ 2원계에 $\mathrm{Sn}$ 분말을 $\mathrm{Cu}$ 첨가량의 $10 \%$ 첨 가하여 소결한 것으로 $\mathrm{W}$ 및 $\mathrm{Cu}-\mathrm{Sn}$ 합금 peak 만 이 관찰되었으며, $\mathrm{W}$ peak의 20 값도 거의 변화가 없 었다. W-Sn 2원계의 경우, 현재 소결특성에 대한 연 구 및 평형상태도[27]에 의하면, $2000^{\circ} \mathrm{C}$ 고온에서 $0.001 \mathrm{at} \%$ 정도의 적은 고용도가 존재하는 것으로 되 어 있지만, 본 실험의 비교적 낮은 $850^{\circ} \mathrm{C}$ 의 소결온 도에서도 거의 상변화가 없는 것으로 관찰되었다.

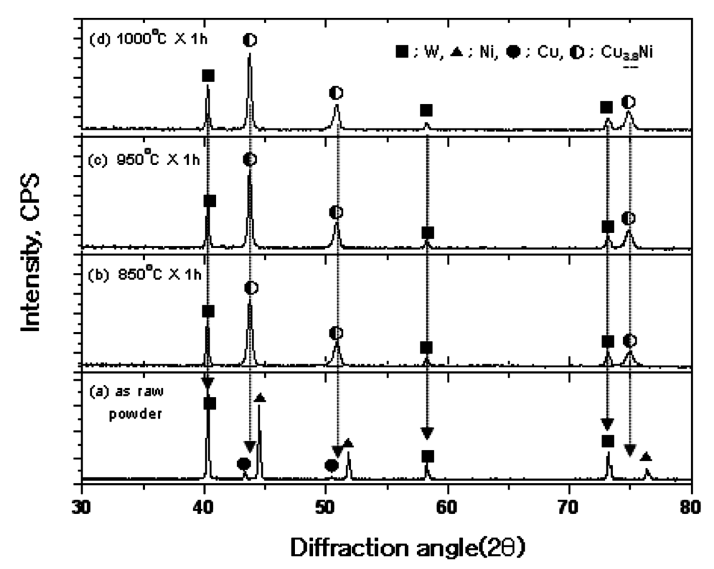

Fig. 7. Comparison of XRD patterns of W-Cu-Ni system samples prepared by sintering conditions; (a)as raw powders, (b) at $850^{\circ} \mathrm{C}$ for $1 \mathrm{hr}$, (c) at $950^{\circ} \mathrm{C}$ for $1 \mathrm{hr}$ and (d) $1000^{\circ} \mathrm{C}$ for $1 \mathrm{~h}$.

그림 7은 $\mathrm{W}-\mathrm{Cu}-\mathrm{Ni}$ 3원계 소결체 시료를 $\mathrm{XRD}$ 로 상을 분석한 결과로서, 소결온도 변화에 따라 큰 상 변화가 발견되지 않았지만, 전 소결체의 시료에서 순 수한 $\mathrm{Cu}$ 및 $\mathrm{Ni}$ 의 peak가 완전하게 소멸되고, 새롭 게 보고된 $\mathrm{Cu}_{3.8} \mathrm{Ni}$ 합금상[28]의 peak가 선명하게 관 찰되었다. 이러한 $\mathrm{Cu}_{3.8} \mathrm{Ni}$ 합금상에 대하여 현재 보 고된 $\mathrm{Cu}-\mathrm{Ni}$ 2원계 평형상태도[29]에는 $\mathrm{Cu}$ 융점이상 의 고온에서 전율 고용체의 형성과 354.5 이하에서 $\mathrm{Cu}$-rich phase $\left(\alpha_{1}\right)$ 과 Ni-rich phase $\left(\alpha_{2}\right)$ 이 존재하는 것 이외의 합금상에 대한 보고는 없다. 이러한 W$\mathrm{Cu}-\mathrm{Ni}$ 3원계 소결체의 치밀화는 주로 $\mathrm{Cu}$ 와 $\mathrm{Ni}$ 의 고 상확산에 의해 $\mathrm{Cu}-\mathrm{Ni}$ 합금상 $\left(\mathrm{Cu}_{3.8} \mathrm{Ni}\right)$ 이 형성됨과 동 시에 W-Ni 2원계의 다양한 금속간 화합물이 생성되 면서 고상소결에 의해 진행된 것으로 추측되었다. 이 러한 이유는 $\mathrm{Cu}-\mathrm{Ni}$ 2원계의 경우에 전율 고용체가 존재하지만, $\mathrm{Cu}$ 의 융점이상에서 액상형성이 가능하 기 때문이며, 또한 $\mathrm{W}$ 와 $\mathrm{Ni}$ 입자들 사이의 경우에도 $\mathrm{W}-\mathrm{Ni}$ 2원계 평형상태도[30]로부터 $\mathrm{Ni}$ 의 융점 $\left(1455^{\circ} \mathrm{C}\right)$ 이하에서는 액상이 존재하지 않으며, $1060^{\circ} \mathrm{C}$ 이하에서 $\mathrm{Ni}_{4} \mathrm{~W}, \mathrm{NiW}$ 및 $\mathrm{NiW}_{2}$ 등의 금속간 화합물이 존재하기 때문이다.

\section{3. 소결체의 밀도 및 경도}

그림 8 및 그림 9 는 그림 5 에 나타낸 $\mathrm{W}-\mathrm{M}(\mathrm{M}=$ $\mathrm{Cu}, \mathrm{Sn}, \mathrm{Ni}$ )계 복합재료 소결체의 밀도 및 경도를 측정한 결과이다. 이들 4 가지 복합재료 소결체의 소 


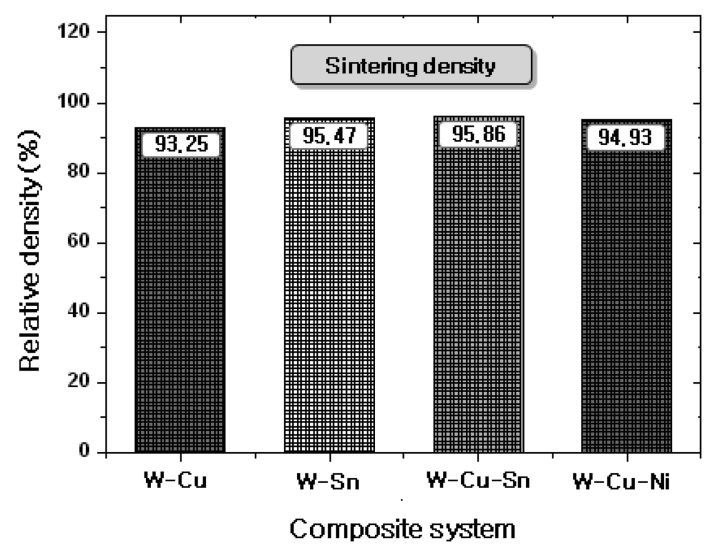

Fig. 8. Comparisons of relative density of sintered W$\mathbf{M}(\mathbf{M}=\mathbf{C u}, \mathbf{S n}, \mathbf{N i})$ system composite samples.

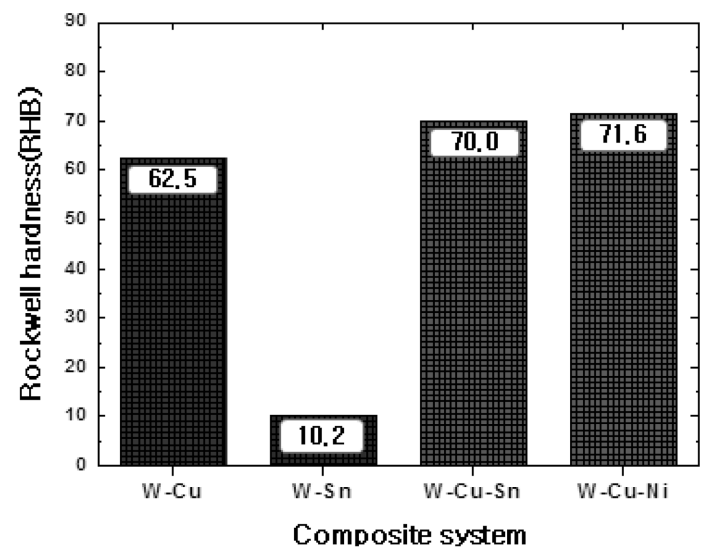

Fig. 9. Comparisons of Rockwell hardness(HRB) of sintered $\mathrm{W}-\mathrm{M}(\mathrm{M}=\mathrm{Cu}, \mathrm{Sn}, \mathrm{Ni})$ system composite samples.

결조건은 각 복합재료의 소결온도를 변화시켜 소결 하여 얻어진 각 복합재료 소결체 중 최고의 밀도가 얻어진 것이다. 각 시료의 소결밀도는 성형밀도보다 모두 증가하여 납 $(\mathrm{Pb})$ 이론비중 $\left(11.34 \mathrm{~g} / \mathrm{cm}^{3}\right)$ 의 $93 \%$ 이상이 얻어졌지만, 특히 W-Cu-Sn 3원계가 $95.86 \%$ $\left(10.87 \mathrm{~g} / \mathrm{cm}^{3}\right)$ 가 얻어져 4 가지 시료 중 가장 큰 밀 도 값을 나타냈다. 이러한 결과는 그림 5 에서 관찰된 미세조직에 잔류하는 기공 정도와도 일치하였다. 그 림 9는 그림 8에 나타낸 4가지 복합재료 소결체의 $\mathrm{HRB}$ 값을 나타낸 것으로 (a)W-Cu 2원계, (c)W-Cu$\mathrm{Sn}$ 3원계 및 (d)W-Cu-Ni 3원계는 62이상으로 비교 적 큰 값이 얻어졌지만, (b)W-Sn계는 10.2로 매우 낮은 값이 얻어졌다.

\section{4. 결 론}

본 연구는 유독성 납 탄환을 대체할 수 있는 새로운 친환경 탄환소재를 개발하기 위한 일환으로, 우선 납 $(\mathrm{Pb})$ 의 이론비중을 목표비중으로 하여 $\mathrm{W}-\mathrm{M}(\mathrm{M}=\mathrm{Cu}$, $\mathrm{Sn}, \mathrm{Ni}$ )계 고밀도 복합재료를 설계하여 $\mathrm{P} / \mathrm{M}$ 법으로 각 소결체를 제조하여 다음과 같은 결과를 얻었다.

1. (a)W-Cu 2원계, (b)W-Sn 2원계, (c)W-Cu-Sn 3원계 및 (d)W-Cu-Ni 3원계로 혼합된 4종류 복합재 료 분말을 동일한 조건으로 압축 성형한 상대밀도는 모두 91\%이상이었으며, 그들 중에서 (b)W-Cu-Sn 3 원계가 $95.90 \%$ 로 가장 높게 나타났다. 그러나 실제 로 성형밀도는 $\mathrm{H} / \mathrm{D}$ 비 및 성형압력 등의 외적 요소 에 크게 의존하므로 이들 값을 변화시키면 더욱 증 가할 것으로 추측되었다.

2. 또한 동일한 조건으로 성형된 각 4종류 복합재 료는 최적의 소결온도를 알아보기 위해 소결시간을 모두 1시간으로 고정하고, 텅스텐 $(\mathrm{W})$ 을 제외한 각 금속분말의 융점이하에서 소결온도를 변화시켜 소결 체의 소결밀도 및 경도를 측정한 결과, 4 종류의 복합 재료 모두 $93 \%$ 정도의 상대밀도가 얻어졌지만, 특히 (b)W-Sn 2원계와 (c)W-Cu-Sn 3원계의 소결밀도가 각각 $95.47 \%$ 및 $95.86 \%$ 로 비교적 높은 소결밀도가 얻어졌으며, 로크웰 경도(HRB)값은 각각 10.2 및 70.0 로 큰 차이를 나타냈다.

이상과 같이 본 연구에서는 주로 $\mathrm{W}$ 를 주성분으로 한 복합재료 소결체의 미세조직, 소결거동 및 물리적 특성 등의 기초적 데이터를 조사한 결과, 특히 W$\mathrm{Cu}-\mathrm{Sn}$ 3원계 복합재료 소결체가 소결특성 및 상대밀 도 등을 고려하면 납탄환의 대체소재로서 우선적으 로 적용 가능성을 나타냈다. 그러나 최종 소결체의 치밀도를 높여 밀도 특성을 더욱 향상시키기 위해서 는 성형압력 및 소결조건 등의 제공정 변수에 대한 보다 상세한 조사가 필요하며, 더욱이 본 연구에서 주요 원료로 사용한 $\mathrm{W}$ 및 $\mathrm{Cu}$ 등은 공업적 수요 증 가로 인해 매우 고가이다. 따라서 최적의 탄환용 고 밀도 복합재료 설계를 위해서는 코스트 문제해결을 위한 노력도 중요한 것으로 사료되었다.

\section{감사의 글}

본 논문은 2005년도 공주대학교 자체학술연구 조 
성비 지원을 받아 수행되었습니다.

\section{참고문헌}

[1] Vernon E. Ryan: U. S. Patent No. 4738,047 (1988)

[2] John E. Brown: U. S. Patent No. 4,949,644 (1990).

[3] Jhon Huffman: U. S. Patent No. 5,189,252 (1993).

[4] Germain Belanger and St. Germain-de-Grantham: U.S. Patent No. 5,237,930 (1993).

[5] Olin Corporation: U. S. Patent No. 5,399,187 (1995).

[6] Idea stumarket Elpi: Korea Patent No. 10-2000-0022324 (2000).

[7] SCM metal products incooperated R. J.: Korea Patent No. 10-1998-0701874 (1998).

[8] Remington arms company: Korea Patent No. 102000-0070539 (2000)

[9] F. Hoffman: Korea Patent No. 10-1998-701776 (1998).

[10] Pungsan (Co., Ltd.): Korea Patent No. 10-0257463.

[11] ADD: Korea Patent No. 10-0363395.

[12] KAIST: Korea Patent No. 10-0375944.

[13] T. H. Kim, J. H. Yu and J. S. Lee: Nano Struct. Mater., 9 (1997) 213.

[14] D. K. Kim, S. H. Lee, H. S. Song and K. J. Park: Journal of the Korean Institute of Metals and Materials, 35 (1997) 45.

[15] K. G. Lee, K. H. Lee, B. G. Lee and D. H. Lee: Journal of the Korean Institute of Metals and Materials, 36 (1998) 104.
[16] Dorfman et al.: U.S. patent No. 5,956,560 (1999).

[17] D. G. Kim, E. P. Kim and Y. D. Kim: Korean Journal of Materials Research, 12 (2002) 16.

[18] D. G. Kim, K. W. Lee, M. J. Seok and Y. D. Kim: Korean Journal of Materials Research, 13 (2003) 169.

[19] H. B. Park, D. J. Cho and C. B. Song: MRSK 8th Conference Proceedings, 5 (2005) 96.

[20] H. B. Park, J. M. Goo and C. B. Song: MRSK 9th Conference Proceedings, 11 (2005) 159.

[21] M. S. Shim, D. S. Kim, Y. H. Oh and C. B. Song: MRSK 11th Conference Proceedings, 11 (2006) 123.

[22] C. B. Song and H. B. Park: Korea Patent No. 10-20070030336 (2007)

[23] C. B. Song and J. M. Goo: Korea Patent No. 10-20070063697 (2007).

[24] C. B. Song, Y. H. Oh and J. M. Goo: Korea Patent No. 10-2007-0075411 (2007).

[25] Y. H. Oh, S. H. Kim and C. B. Song: MRSK Twelfth Conference Proceedings, 5 (2007) 55.

[26] Y. H. Oh, T. S. Jang, J. H. Hong and C. B. Song: MRSK 13th Conference Proceedings, 11 (2007) 164.

[27] Massalski, T. B.: Binary Alloy Phase Diagram, Sn-W alloy System, ASM, Metals Park, Ohio, 3 (1986) 3411.

[28] JCPDS-ICDD 2000(PDF \#090205): Ref. Long, Frazer, Ott, J. Am. Chem. Soc., 56 (1934) 1101.

[29] Massalski, T. B.: Binary Alloy Phase Diagram, Cu-Ni alloy System, ASM, Metals Park, Ohio, 3 (1986) 1444.

[30] Massalski, T. B.: Binary Alloy Phase Diagram, Ni-W alloy System, ASM, Metals Park, Ohio, 3 (1986) 2883. 